\title{
REGIONALIZATION AND MAPPING OF DISSOLVED OXYGEN CONCENTRATION OF SAKARYA BASIN BY L-MOMENTS METHOD
}

\author{
Hatice CITAKOGLU ${ }^{1 *}$, Betul Tuba GEMICI², Alev DEMIR ${ }^{1}$ \\ ${ }^{1}$ Erciyes Üniversitesi, Mühendislik Fakültesi, İnşaat Mühendisliği Bölümü, Kayseri, Türkiye \\ ${ }^{2}$ Bartın Üniversitesi, Mühendislik, Mimarlık ve Tasarım Fakültesi, Çevre Mühendisliği Bölümü, Bartın, Türkiye
}

\begin{tabular}{l}
\hline Keywords \\
\hline L-Moments, \\
Inverse Distance Weighted \\
Interpolation Method, \\
Dissolved Oxygen, \\
Sakarya Basin.
\end{tabular}

\begin{abstract}
In this study, a regionalization study was conducted with the L-Moments method in order to determine the change of dissolved oxygen (DO) required to sustain the life of aquatic organisms in a given return period and also to consider the effects of all stations. Dissolved oxygen concentration data of 20 meteorological stations for spring months were evaluated between 1995 and 2014 in Sakarya Basin, Turkey. Firstly, Homogeneity Criterion $\left(h_{1}\right)$ statistical results have been determined that the study area is not uniformly homogeneous in Sakarya Basin $\left(h_{1}=18.01>1.0\right)$. In order to implement the L-Moments method, the Sakarya Basin is divided into five homogeneous regions considering the topographic characteristics of the basin. In the second phase of the study, L-Moments method; Wakeby distribution proposed by Hosking parameters were estimated. By using the parameter values of the Wakeby distribution, statistical dimensionless DO content values corresponding to the periodic repetition periods were obtained. In the last stage of the study; 50,100, 200,500 and 1000 years repetitive thematic DO content maps were created by using Inverse Distance Weighted interpolation method (IDW) with the aim of visually expressing DO content data estimated by L-Moments method.
\end{abstract}

\section{SAKARYA HAVZASI ÇÖZÜNMÜŞ OKSİJEN KONSANTRASYONUNUN L-MOMENTLERİ YÖNTEMİ İLE BÖLGESELLEŞTIRILIMESI VE HARITALANMASI}

\begin{tabular}{l} 
Anahtar Kelimeler \\
\hline L-Moments, \\
Ters Mesafe Ağırlıklı \\
Enterpolasyon Yöntemi, \\
Cözünmüs oksijen, \\
Sakarya Basin.
\end{tabular}

Alıntı / Cite

Citakoglu, H., Gemici, B. T., Demir, A., (2021). Regionalization and Mapping of Dissolved Oxygen Concentration of Sakarya Basin by L-Moments Method, Mühendislik Bilimleri ve Tasarım Dergisi, 9(2), 495-510.

\begin{abstract}
Bu çalıșmada, belirli bir dönüs periyodunda suda yaşayan organizmaların yaşamını sürdürmek için gerekli olan çözünmüş oksijen (DO) değişimini belirlemek ve ayrıca tüm istasyonların etkilerini göz önünde bulundurmak için L-Moments yöntemi ile bölgeselleştirme çalışması yapılmıştır. Sakarya Havzası'nda ilkbahar ayları için 20 meteoroloji istasyonunun çözünmüș oksijen konsantrasyonu verileri 1995-2014 yılları arasında değerlendirilmiștir. İlk olarak, Homojenlik Kriteri $\left(\mathrm{h}_{1}\right)$ istatistiksel sonuçları, çalıșma alanının Sakarya Havzası'nda $\left(\mathrm{h}_{1}=18.01\right.$ > 1.0) tekdüze homojen olmadığı belirlenmiştir. L-Momentleri yönteminin uygulanması için Sakarya Havzası, havzanın topografik özellikleri dikkate alınarak beş homojen bölgeye ayrılmıştır. Araştırmanın ikinci aşamasında, L-Momentler yöntemi; Hosking parametreleri tarafından önerilen Wakeby dağılımı tahmin edildi. Wakeby dağılımının parametre değerleri kullanılarak periyodik tekrar periyotlarına karşılık gelen istatistiksel boyutsuz DO içerik değerleri elde edilmiştir. Çalışmanın son aşamasında; L-Moments yöntemi ile tahmin edilen DO içerik verilerini görsel olarak ifade etmek amacıyla Ters mesafe ağırlıklı enterpolasyon yöntemi (IDW) kullanılarak 50,100, 200, 500 ve 1000 yıllık tekrarlayan tematik DO içerik haritaları oluşturulmuştur.
\end{abstract}

\footnotetext{
* ilgili yazar / Corresponding author: hcitakoglu@erciyes.edu.tr
} 


\begin{tabular}{l|l|l}
\hline Yazar Kimliği / Author ID (ORCID Number) & \multicolumn{3}{|l}{ Makale Süreci / Article Process } \\
\hline H. Citakoglu, 0000-0001-7319-6006 & Başvuru Tarihi / Submission Date & 24.12 .2020 \\
B. T. Gemici, 0000-0003-1731-536X & Revizyon Tarihi / Revision Date & 10.03 .2021 \\
A. Demir, 0000-0002-6636-7425 & Kabul Tarihi / Accepted Date & 28.03 .2021 \\
& Yayım Tarihi / Published Date & 20.06 .2021 \\
\hline
\end{tabular}

\section{Introduction}

The contamination of water sources due to various reasons limits the use of water. There are many factors that can cause changes in the quantity and quality of water, such as climate change, population, industrial development and changes in land use (Haddeland et al., 2016; Kundzewicz and Krysanova, 2010; Cheng et al., 2018). Freshwater among water sources has always attracted great attention due to its ecological and chemical condition (Diamantini et al., 2018). Especially rivers are the most threatened ecosystems as a receiving environment not only for drinking water supply, but also for water sports, fishing, transport, irrigation of water and tourism in the world (Shanbehzadeh et al., 2014). The rivers are especially polluted by sewage, factory waste, pesticide and fertilizer as a result of agricultural activities. These factors cause changes in the physical, chemical and biological properties of the water quality of river (Granger et al., 2010; Mainali and Chang, 2018).

The concentration of dissolved oxygen (DO) is an important river water quality parameter in terms of providing information about the status of water ecosystems. In other words, DO level is a measure of the health of the water system. DO concentration is frequently used to assess water quality in different reservoirs and watersheds. Therefore, dissolved oxygen modeling and statistical analysis is very important for river water quality analysis (Ay and Kisi, 2012; Kisi et al., 2013).

Monitoring of water quality is significant for determining temporal and spatial changes in aquatic environment, detecting factors affecting water sources, and assessing the effectiveness of preservation of water (Hirsch et al., 2010; Gonzales-Inca et al., 2016). However, the assessment of long-term water quality changes is also a challenging problem. An important issue in the management of water resources is the availability of accurate data (Halbe et al., 2013; Khalil et al., 2016). Additionally, the lack of meteorological, hydrological and water quality data is a major problem in most regions. In some cases, data are not available in essential region and, if data are available, records are either too short or incomplete to obtain adequate hydrological and water quality conditions (Khalil et al., 2016; Alley and Burns, 1983). Many statistical analysis methods are available to address these problems. The L-Moments method is a widely used method for solving various problems related to parameter estimation, regionalization and distribution definition. The L-Moments method was introduced by Hosking (1990) and is the linear combinations of probability-weighted moments. It is easier and more suitable to describe the shape of the distribution by the L-Moments method than the probability-weighted moments method. This method has the ability to summarize statistical distribution in a more meaningful way. Also, this method exhibit relatively small changes. Hosking and Wallis (1993) has developed numerous tests for use in regional studies.

The L-Moments method is commonly used by researchers in regional analysis of flood frequency, annual maximum flow, annual maximum rainfalls and low flows. Citakoglu et al. (2017) carried out regional flood frequency analysis with L-Moments method using the annual maximum flow data observed at 52 current observation stations in the streams into the Black Sea. In this study Generalized Normal Distribution showed the best probability distribution in five of eleven sub-regions. Generalized Extreme Values, Pearson Type 3, Generalized Logistics distributions were found to be the best in three, two and one sub-regions respectively. Chen et al. (2006) conducted a regional low-flow frequency analysis using the L-Moments method with a typical annual 7-day low flow for Dongj iang basin, South China. For these 14 regions, the three-parameter lognormal (LN3) distribution was better matched than generalized logistics (GLO), generalized over-value (GEV), Pearson type III (PIII), and generalized Pareto (GPD) distributions. Kumar and Chatterjee (2005) performed regional flood frequency analysis using the L-moments method for North Brahmaputra Region of India and Extreme Value distribution, Normal distribution and Pearson Type III distributions were found suitable for this region. Seckin et al. (2010) tested the homogeneity of the annual maximum flows of 19 stations in the Ceyhan basin using the L-moments method. They have applied the distributions commonly used in the literature to 2 homogeneous sub-regions and determined that The Generalized Logistic distribution (GLO) is suitable for both sub-regions. Anli et al. (2006) conducted a regional flood frequency analysis for the Göksu Basin by L-moments. The Extreme Value distribution was found to be the most suitable distribution in this analysis. Haktanir et al. (2016) applied the regional index flood method with the L-Moments approach to successive-duration annual maximum rainfall (AMR) series between 5 minutes and 24 hours. However, in the literature, it was observed that L-Moments model studies related to river water quality parameters were limited. Khalil et al. (2016) conducted many methods including the L-Moments to maintain the water quality variable characteristics by using water quality records obtained from the Nile Delta water quality monitoring network in Egypt. In this study, they stated that L-moments 
method is better than other methods by producing extended records that maintain variance as well as excess percentages.

The aim of this study was to analyze the dissolved oxygen data between 1995 and 2014 in 20 meteorology stations for Sakarya Basin by using L-Moments method and to obtain a regional DO value for various return periods. Thus, reasonable estimates of monthly DO values can be made in the recurrence periods between 2 years and 1000 years in stream sections without DO measurements. First stage of the study, the homogeneous regions determined according to the homogeneity test L-Moments method was separated in the Sakarya basin for reasonable estimates. In the second stage of the study, dimensionless DO values were obtained with the help of various probability distributions. Third stage of the study, the average DO value given by the regression equation developed for the Sakarya basin is multiplied by any repetitive dimensionless DO value. At the last stage of the study, maps were developed for various repetition periods using the data of all observation stations.

\section{Materials and Methods}

\subsection{L-Moments and $\mathrm{L}-$ Coefficients}

Since the detailed information about the theory and application of L-Moments method is explained in detail in many studies (Hosking, 1990; Hosking and Wallis, 1997), L-Moments method is given in this subsection in summary. The probability-weighted moments presented by Greenwood et al. (1979) are shown in Eq.(1).

$$
\beta=\int_{0}^{1} x(F) \cdot F^{j} \cdot d F
$$

Here $F=F(x)$ of the random variable $x$ the cumulative distribution function (CDF); $x=x(F)$, variable in function is defined as, Inverse of CDF; and $\beta_{j}$, j's probability-weighted momentum. $j=0$ (1) as can be seen, the probability of 0 is equal to the overall mean of the moment distribution. Similarly, to conventional moments, the parameters are calculated using the analytical relationships between the parameters of the distribution and the $\beta_{j}$ 's. Therefore, the first three $\beta_{j}(j=0,1,2)$ for 3-parameter distributions, first four $\beta_{j}(j=0,1,2,3)$ for 4-parameter distributions (for example: for the Kappa distribution), first five $\beta_{j}(J=0,1,2,3,4)$ for the parameter Wake by distribution it is estimated from the current observed series at hand.

Linear Moments (L-Moments) are expressed as linear combinations of probability-weighted moments given in Eq.(1) as follows Eq. (2 a-d) (Hosking and Wallis, 1997),

$$
\begin{aligned}
& \lambda_{1}=\beta_{0} \\
& \lambda_{2}=2 \beta_{1}-\beta_{0} \\
& \lambda_{3}=6 \beta_{2}-6 \beta_{1}+\beta_{0} \\
& \lambda_{4}=20 \beta_{3}-30 \beta_{2}+12 \beta_{1}-\beta_{0}
\end{aligned}
$$

Here, $\lambda \mathrm{j}$ is the $\mathrm{L}$-moment in $\mathrm{j}$. The $\mathrm{L}$-coefficients of the distribution with the ratio of $\mathrm{L}-$ moments are as follows it is defined Eq. (3-5) as (Anli et al., 2007):

$$
\begin{aligned}
& \tau \equiv L-\text { variation }=\lambda_{2} / \lambda_{1} \\
& \tau_{3} \equiv L-\text { skewness }=\lambda_{3} / \lambda_{2} \\
& \tau_{4} \equiv L-\text { kurtosis }=\lambda_{4} / \lambda_{2}
\end{aligned}
$$

L-variance coefficient $\tau \tau$ is the function of the conventional variance coefficient (standard deviation $/ \mu$ ), in other words, the probability density function is described by Hossing and Wallis (1997) where the density function is quantifiable. Similarly, the probability density of the L-skew factor $\tau_{3}$ curvature of function and the L-kurtosis coefficient represents the degree of modality of the probability density function of $\tau_{4}$, and quantitatively represent her sharpness. Conventional coefficients are very large take values at intervals, and this is an advantage.

The basis of the L- moments method is based on the L-moments ratios calculated from the series observed at each station. L-variation, L-skewness and L-kurtosis coefficients regional probability distribution parameters are calculated using the weighted averages calculated by proportion of the defined proportions to the series lengths (Hossing and Wallis, 1997). In the L-moments method, since Dalrymple's index-flood model was used in 1960, all elements of each recorded series are divided into their average value, since Dalrymple's index-flood model was used in 1960, all elements of each recorded series are divided into their average value (Dalrymple, 1960a). 
Candidate from distributions, test called aptitude test, $Z^{\text {DIST }}$ L- kurtosis coefficients for L-Skewness coefficients of the relationship is chosen as the most appropriate relationship to the region closest to the theoretical distribution. In the homogeneous region, the mean rate of DO is obtained by multiplying the standardized frequency curve, also called the growth curve, or the value given by the standardized variable function defining this curve by the mean rate of DO, which is estimated at that point. For a region where frequency analysis is determined to be homogenous, the following equation is used in the calculation of an average return periods DOQ for a region that is determined to be homogenized in terms of frequency analysis are given by Eq. (6):

$$
Q_{T}=x(F) \times \mu
$$

In this equation; $\mu$, is the amount of dissolved oxygen in the geographic point at which the average return period is $\mathrm{T}$ year. $\mathrm{F}$ is the probability of a small-residual (non-transcendence) of the dissolved T-year mean dissolved oxygen amount associated with the expression of the mean return periods $F=1-1 / \mathrm{T}$ [or, $\mathrm{T}=1 /(1-\mathrm{F})]$. $\mathrm{x}(\mathrm{F})$, the average of the cumulative function for the homogeneous region to the standard DO value $(\mu=1)$ which is equal to the one $(\mu=1)$. $\mu$ is the average of DO at that geographic point. Regional index- the origin of flood method (Eq. 6), which is common in Dalrymple and Hossing-Wallis methods (Hosking and Wallis, 1997; Dalrymple, 1960b).

\subsection{Nonconformity Criteria According to L-Moments Method}

The nonconformity criterion is used to determine the L-coefficients in a homogenous region, where the L-coefficients may be too far away from the average of the L-coefficients of the compatible stations. The measure of nonconformity depends on the number of stations in the region. A mismatched station is extracted from the L-Moments-based regionalization analyses in the homogenous region in question. The nonconformity criterion is calculated by the L-coefficients of Station data and expressed in the following formula by Eq. (7):

$$
D_{i}=\left(\frac{1}{3}\right) \cdot N \cdot\left(u_{i}-\bar{u}\right)^{T} A_{H}^{-1} \cdot\left(u_{i}-\bar{u}\right)
$$

$\mathrm{u}_{\mathrm{i}}$ : L-variation, L-skewness, L- kurtosis matrix of coefficients

T: Transpose of Matrix

$\mathrm{u}$ : weightless group average

$A_{\mathrm{H}}$ : the matrix of the sum of the squares and the cross product

$D_{i}$ : measure of mismatch for i station

If the number of stations in the homogeneous region is greater than 15, the calculated value of $D_{i}$ is considered to be incompatible with the station (discordant) greater than 3 (Hosking and Wallis, 1997).

\subsection{Homogenization Test According to L-Moments Method}

In order to determine whether the series recorded at point stations conforms to the general homogeneity criterion in the homogeneous region, the L-Moments based homogeneity test is developed by Hossing and Wallis, 1997 and symbolized by the $H k$ statistics are given by Eq. (8).

$$
H_{k}=\left(V_{k}-\mu_{v}\right) / \tau_{v}
$$

In this equation, $\mathrm{k}=1,2,3$ and three different $\mathrm{h}_{k}$ are defined, $\mathrm{h}_{1}$ is more deterministic because it depends on the L-variability coefficient according to their Hosking, 1990 experience and $\mathrm{h}_{1}$ is more important.

$\mathrm{V}_{\mathrm{k}}$ is the weighted standard deviation of the L-coefficient in $\mathrm{k}, \mu_{\mathrm{v}}$ and $\sigma_{\mathrm{v}}$ is the mean and standard deviation of $\mathrm{V}_{\mathrm{k}}$ values from 500 synthetic series. If the value of homogeneity statistic is less than $1\left(\mathrm{~h}_{k}<1\right)$, the region is definite homogeneous, $1<\mathrm{h}_{k}<2$ the region can be assumed to be homogeneous, in $\mathrm{h}_{k}>2$, the region is definitely considered heterogeneous (Hosking and Wallis, 1997).

\subsection{Choosing the Optimal Distribution According to L-Moments Method}

In order to determine the optimal probability distribution to represent the homogenous region, 500 synthetic series are produced with parameters calculated from the L-coefficients of the region and their lengths equal to the average length of the recorded series. This series is calculated from the L-Skewness corresponding to the marked coefficient of L-Kurtosis coefficients of the points of the candidate theoretical distributions in the L-coefficient of Skewness for the corresponding L-Kurtosis coefficient homogeneous distribution within a certain confidence interval the curves of the quantitative differences that could represent the region as the potential distributions are considered. The standard normal distribution is a random variable whose default is $Z^{\text {DIST }}$, and the numerical value 
of this statistic is calculated by using the following expressions, distributions with $90 \%$ confidence interval limits of $-1.64<Z^{\mathrm{DIST}}<+1.64$ inequality are distributions that represent the regional distribution of the DOQ in the homogeneous region. The $Z^{\text {DIST }}$, value from the remainder of this range to zero the distribution can be regarded as the most appropriate distribution for the region near. From the rest in this range, the value of $Z^{\text {DIST }}$, which is closest to zero can be regarded as the most appropriate distribution for the region scatter. $Z^{\text {DIST }}$ statistics are calculated by Eq. (9-11) comparing the following equations:

$$
\begin{aligned}
& \beta_{4}=N_{S I M}^{-1} \cdot \sum_{m=1}^{N_{S I M}} \tau_{4}^{m}-\tau_{4}^{R} \\
& \sigma_{4}=\left\{\left(N_{S I M}-1\right)^{-1} \cdot\left[\sum_{m=1}^{N_{S I M}}\left(\tau_{4}^{m}-\tau_{4}^{R}\right)^{2}-N_{S I M .} \beta_{4}^{2}\right]\right\}^{0.5} \\
& Z^{D I S T}=\left(\tau_{4}^{D I S T}-\tau_{4}^{R}+\beta_{4}\right) / \sigma_{4}
\end{aligned}
$$

In these equations, $\tau_{4}^{R}$ and $\tau_{4}^{m}$ are regional L-Basque coefficients calculated from the recorded series and the simulation in $\mathrm{m} ; \beta_{4}$, is the correction term for the bias in the estimation of the regional mean L-squared coefficient.; $\sigma_{4}$, is the standard deviation of the Regional mean L-Basque coefficient calculated from the recorded series.; $\tau_{4}^{D I S T}$, is the theoretical L-squared coefficient of the candidate probability distribution. $\mathrm{N}_{\text {sim }}$ is the number of simulation (synthetic series) performed by Kappa distribution. As recommended by Hosking and Wallis (1997) $\mathrm{N}_{\text {sim }} 500$ was taken in this study.

In this study, the computer program developed by Hosking was used. This program is available on the website, URL, 2020.

In addition to the $Z^{D I S T}$ test, a visual test is also available to select the appropriate distribution for the DOQ data in a homogeneous region. Here, the theoretical relationships between L-Squared $\left(\tau_{4}\right)$ and L-Squared $\left(\tau_{3}\right)$ coefficients of all potential distributions are drawn and the L-Squared $\left(t_{4}\right)$ and L-Squared $\left(t_{3}\right)$ coefficients of the observed series in the stations within the homogenous region are indicated in the same graph. The distribution of points that are marked closest to the theoretical curves of distributions is generally compatible with the $Z^{\text {DIST }}$ test result.

\section{Estimation of DO Series Mean by Regression Analysis}

It is possible to define regression analysis as the change of a dependent variable depending on one or more independent variables. The difference of multiple linear regression analysis from simple regression analysis used in this study is that it is related to more than one independent variable (number of independent variables $\mathrm{m}$ ) rather than a single independent variable (Helsel et al., 2002; Heperkan and Kesgin, 2003; Montgomery and Peck, 2001). In simple linear regression analysis, individual analysis is performed for each of the independent variables. In this case, since the number of variables is more than one, the analysis cannot be expressed graphically (Heperkan and Kesgin, 2003).

For multiple linear regression analysis, we can express y dependent variable according to m independent variables as given in the following equation:

$$
y=\alpha_{0}+\alpha_{1} \cdot x_{1}+\alpha_{2} \cdot x_{2}+\ldots+\alpha_{t} \cdot x_{t}+\ldots+\alpha_{m} \cdot x_{m}+\varepsilon
$$

In regression analysis, it is possible to establish a relationship between the coefficients of the independent variables and the dependent variable. Such that the coefficients of the arguments $\left(\alpha_{1}, \alpha_{2}, \ldots, \alpha_{\mathrm{m}}\right)$ between the dependent variable values based on whether it receives positive or negative increases-increases as decreasing, or increasing, it can be said there is a relationship. In this equation $\varepsilon$ is the margin of error when trying to estimate the dependent variable $y$.

A hypothesis is a proposition put forward about a situation. In regression analysis, hypothesis tests are performed to determine whether the relationship between variables is strong. The hypothesis is that a pre-determined mass parameter is compared and tested with the parameter of the resulting sample mass. When making decisions about the parameters of the main mass, decisions that are likely to be true or false are acted upon. The hypothesis is considered correct if the sample statistic is close to the parametric value tested. However, if the sample statistic is very different from the parametric value tested, the hypothesis is not considered correct, the hypothesis is rejected.

- If $\mathbf{H}_{\mathbf{0}}: \mathbf{B}=\mathbf{0}$, the 1-unit change in $\mathrm{X}$ at the main mass does not affect $\mathrm{y}$, so there is no relationship between the two variables. (Null hypothesis) the hypothesis that the population parameter does not have a significant difference 
between the default real value and the estimated value prior to the investigation and that the difference is due to chance is called the "zero hypothesis". The situation we believe is in the $\mathrm{H}_{0}$ hypothesis. The $\mathrm{H}_{0}$ hypothesis is considered correct unless it can be proved otherwise. Therefore, when creating a zero hypothesis, it is considered to be statistically complete and clear. The zero hypothesis, in the sense that there is no difference, is formulated with equality and is established for the purpose of rejection.

- If $\mathbf{H}_{1}: \mathbf{B} \neq \mathbf{0}$, the 1-unit change in $\mathrm{X}$ at the main mass affects $\mathrm{y}$, so the relationship between the two variables is important. (Alternative hypothesis) the alleged case is addressed in the $\mathrm{H}_{1}$ hypothesis. The hypothesis that contains a judgment opposite to the one stated in the zero hypothesis is called the alternative hypothesis $\left(\mathrm{H}_{1}\right)$. The obligation to prove itself belongs to the $\mathrm{H}_{1}$ hypothesis. The $\mathrm{H}_{1}$ hypothesis is always expressed as the inverse of the $\mathrm{H}_{0}$ hypothesis. The hypothesis that will be accepted if the zero hypothesis is rejected is called the "alternative hypothesis".

The steps of hypothesis testing are: determination of Ho, determination of $\mathrm{H}_{1}$, determination of severity ( $\alpha$ ), selection of sample volume (n), selection of test statistics, calculation of critical value, data collection, and calculation of test statistics, statistical decision making and interpretation.

In hypothesis testing, when determining the test statistic, if standard deviation is known for mean or two mean differences; $\mathrm{Z}^{\mathrm{DIST}}$ test if standard deviation is not known; $\mathrm{Z}^{\mathrm{DIST}}$ test if $\mathrm{n} \geq 30$, $\mathrm{t}$ statistic if $\mathrm{N}<30$ is applied. In the test of variances, the $\mathrm{F}$ statistic is used for the ratio of two variances.

The $t$ test is used to determine whether the coefficients of the independent variables obtained as a result of regression analysis are statistically significant. For this reason, the $t$ value of the coefficient of each independent variable is calculated. See if the calculated t stays within the $\% 99$ confidence interval limits. The critical value $t$, which determines the limits of this confidence interval, is taken from the student's t distribution, depending on the degree of freedom and half of the complement of the confidence interval probability selected (\% $0.5, \% 2.5$ or $\% 5)$.

If the calculated $t$ value provides the $-t_{\mathrm{kr}}<\mathrm{t}<\mathrm{t} \mathrm{kr}$ inequality, it means that the $\mathrm{xj}$ argument is meaningless and must be excluded from the regression model. If $t<-t_{k r}$ or $t>t_{k r}$, the $x j$ argument used to estimate $y$ is meaningful and must be present in the regression expression (Haktanir, et al. 2013, Citakoglu, 2015, Yağbasan et al. 2020).

In addition to determining whether the candidate arguments are meaningful with the help of the test, the case that any candidate independent variable is dependent on the other independent variables should also be tested. This is referred to in the literature as 'Variance Inflation Factor (VIF)' analysis.

If $\mathrm{m}$ is one of the independent variables, for example $\mathrm{j}^{\prime}\left(\mathrm{x}_{\mathrm{j}}\right)$ is dependent on other $\mathrm{m}-1$ independent variable with a high coefficient of determination, such as a dependent variable, this does not make a concrete contribution to the healthy prediction of $\mathrm{x}_{\mathbf{j}}$. The coefficient of determination is deceptively high. In this case, it is said that there is multi-collinearity among some candidate independent variables.

$* \mathrm{VIFj}<5$ arguments can be used in the model or in regression.

*VIFj > 5 arguments must be removed from the model or regression (Haktanir, et al. 2013, Citakoglu, 2015).

The coefficient of determination is a measure of how close the regression analysis is to the real situation. When looking at the significance of the coefficient of determination in the regression analysis, if $\mathrm{F} \geq$ Fkr the significance condition is provided.

In this study, it is tried to make estimation in order to find the average value of the existing DO series and the regions where there are no stations in the Sakarya Basin. A suitable regression model was sought; t test, f test, VIF values were taken into consideration. Minitab package program was used for this stage. The results of the regression analysis were shared and explained in the findings and discussion section.

\section{Inverse Distance Weighted Interpolation Method (IDW)}

Inverse distance weighted interpolation method (IDW); It can be said that it is the most commonly used method in non-geostatistics Geographic Information Systems (GIS). Geostatistics is a statistical calculation method that takes into account the relationship between samples and the coordinates from which the samples are taken. However, the IDW method is a regional intermediate value estimation method, as it can only generate estimates from neighboring points. This method makes the estimation of unknown points by using the distance between the points in the weight calculation. It can be said that the IDW method is based on the fact that the nearby points have a higher weight on the surface to be interpolated than the distant points. It is mainly based on the mathematical 
function known as the Shepard's Method. In equation 13, the data used in the estimation are expressed as any exponent of the distance inversely proportional to the distance. In other words, spatial analysis is performed for an unknown point by giving higher values to close distances than distant distances (Dogan et al., 2013).

$$
\begin{aligned}
& \mathrm{F}(\mathrm{x}, \mathrm{y})=\sum_{\mathrm{i}=1}^{\mathrm{n}} \mathrm{w}_{\mathrm{i}} \mathrm{f}_{\mathrm{i}} \\
& \mathrm{w}_{\mathrm{i}}=\frac{\mathrm{h}_{\mathrm{i}}^{-\mathrm{p}}}{\sum_{\mathrm{j}=1}^{\mathrm{n}} \mathrm{h}_{\mathrm{i}}^{-\mathrm{p}}}
\end{aligned}
$$

In this interpolation process the value "p" shows the exponent. The sum of these values must be 1 when showing the weights " $w_{i}$ ". $h_{i}$ is the spatial distance between the sample points and the points to be interpolated (Dogan et al., 2013).

In this study, the function given in equation 13 was run with ArcGIS 10.5, a GIS software, and thematic maps of each homogeneous region were obtained with available DO data. IDW is an intermediate value generating mechanism within the GIS system and the maps prepared by this method are presented in the findings and discussion section.

\section{Results and Discussion}

In this study, dissolved oxygen data of the spring months (March, April and May) obtained from 20 meteorological stations between 1995 and 2014 were examined. The locations of 20 meteorological stations used in this study are shown in Fig. 1. In the first part of the study, L-Moments ratios with L-Skewness, L-Kurtosis, L-Variation coefficients were calculated for all stations using DO data. Table 1 shows L-Skewness, L-Kurtosis, L-Variation coefficients of 20 stations. In addition to the regionalization study, these ratios were used to measure nonconformity and homogeneity tests for all meteorological stations. Before starting the regionalization study, nonconformity test and homogeneity test were performed among 20 stations. As can be seen in table 1; since Di value is less than 3 of all stations, none of the stations used in the study were found to be incompatible. Therefore, the study was continued with all the stations in the region. Besides this, the $\mathrm{h}_{1}$ value obtained as a result of homogeneity test shows that this region covering the whole Sakarya Basin was not homogeneous but heterogeneous $\left(h_{1}=18.01>>1\right)$. Considering the geographical conditions and homogeneity test of the Sakarya Basin, the basin should be divided into homogeneous sub-regions according to $\mathrm{H}_{1}$ criteria. When the study area was divided into homogenous sub-regions, the physiographic and hydrological characteristics of the basin were utilized. At this stage, ArcMap program and Google Earth were used. Sakarya Basin is divided into 5 homogeneous sub-regions such that $\mathrm{H}_{1}$ values, which are homogeneity criteria, are less than 2 . Observation stations for 5 homogeneous regions and $\mathrm{H}$ test statistics are shown in Table 2. While the basin was divided into regions, the nonconformity criterion test was repeated and according to this criterion, all stations in 5 regions were found to be compatible.5 homogeneous regions and stations belonging to these regions are shown in Fig. 2.

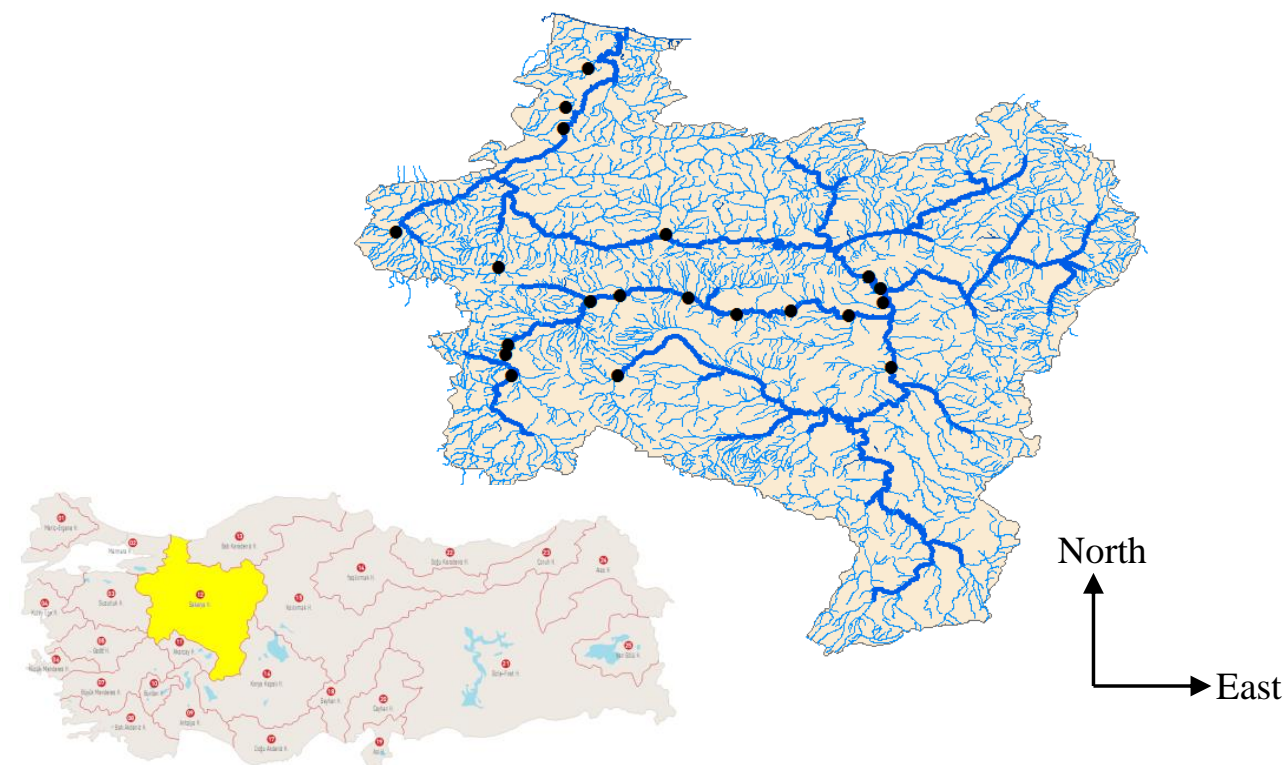

Figure 1. Settlement map of 20 stations belonging to Sakarya Basin 
Table 1. L-variation, L-skewness, and L-kurtosis coefficients and Discordance Measure of 20 stations in the Sakarya Basin.

\begin{tabular}{|c|c|c|c|c|c|}
\hline $\begin{array}{l}\text { Stations } \\
\text { Name }\end{array}$ & $\begin{array}{l}\text { Sample Size } \\
\text { (years) }\end{array}$ & $\begin{array}{c}\text { L-variation } \\
\left(\tau_{2}\right)\end{array}$ & $\begin{array}{c}\text { L-skewness } \\
\left(\tau_{3}\right)\end{array}$ & $\begin{array}{c}\text { L-kurtosis } \\
\left(\tau_{4}\right)\end{array}$ & $\begin{array}{c}\text { Discordance } \\
\text { Measure } \\
\text { D(i) }\end{array}$ \\
\hline 1 & 20 & 0.0943 & 0.0497 & 0.1553 & 0.82 \\
\hline 2 & 20 & 0.0706 & 0.0487 & 0.2601 & 1.00 \\
\hline 3 & 44 & 0.0829 & -0.0219 & 0.1732 & 0.77 \\
\hline 4 & 20 & 0.166 & -0.0372 & 0.1176 & 1.28 \\
\hline 5 & 20 & 0.188 & -0.0333 & 0.0455 & 0.88 \\
\hline 6 & 20 & 0.0662 & 0.1273 & 0.2758 & 1.44 \\
\hline 7 & 20 & 0.389 & 0.1571 & -0.0257 & 1.00 \\
\hline 8 & 20 & 0.41 & 0.2463 & 0.0443 & 1.00 \\
\hline 9 & 20 & 0.272 & 0.2183 & 0.1297 & 1.22 \\
\hline 10 & 20 & 0.149 & 0.121 & 0.2761 & 1.00 \\
\hline 11 & 20 & 0.0757 & 0.0415 & 0.2350 & 1.00 \\
\hline 12 & 20 & 0.134 & 0.061 & 0.1697 & 1.00 \\
\hline 13 & 20 & 0.127 & -0.0979 & 0.22 & 1.00 \\
\hline 14 & 20 & 0.1150 & 0.0463 & 0.1905 & 1.31 \\
\hline 15 & 21 & 0.0783 & -0.0308 & 0.2563 & 1.21 \\
\hline 16 & 43 & 0.1040 & -0.0362 & 0.1672 & 0.45 \\
\hline 17 & 20 & 0.239 & 0.0812 & 0.0704 & 0.33 \\
\hline 18 & 20 & 0.268 & 0.0964 & 0.1041 & 1.28 \\
\hline 19 & 19 & 0.434 & 0.1825 & -0.0139 & 1.00 \\
\hline 20 & 20 & 0.0591 & -0.0035 & 0.3761 & 1.00 \\
\hline
\end{tabular}

Table 2. Stations of homogeneous regions and $\mathrm{H}$ test statistics

\begin{tabular}{lllll}
\hline Basin Areas & Station Numbers & H $_{1}$ statistics & $\boldsymbol{H}_{2}$ Statistics & H $_{3}$ Statistics \\
\hline Region 1 & $7-8-19$ & $-0.91<<1$ & -1.09 & -1.27 \\
Region 2 & $1-3-6-14-15-16$ & $0.54<<1$ & -1.14 & -1.67 \\
Region 3 & $4-5-9-17-18$ & $1<<1.17^{*}<<2$ & 0.48 & -0.47 \\
Region 4 & $10-12-13$ & $-0.94<<1$ & -0.05 & -0.36 \\
Region 5 & $2-11-20$ & $-0.45<<1$ & -1.45 & -1.24 \\
\hline
\end{tabular}




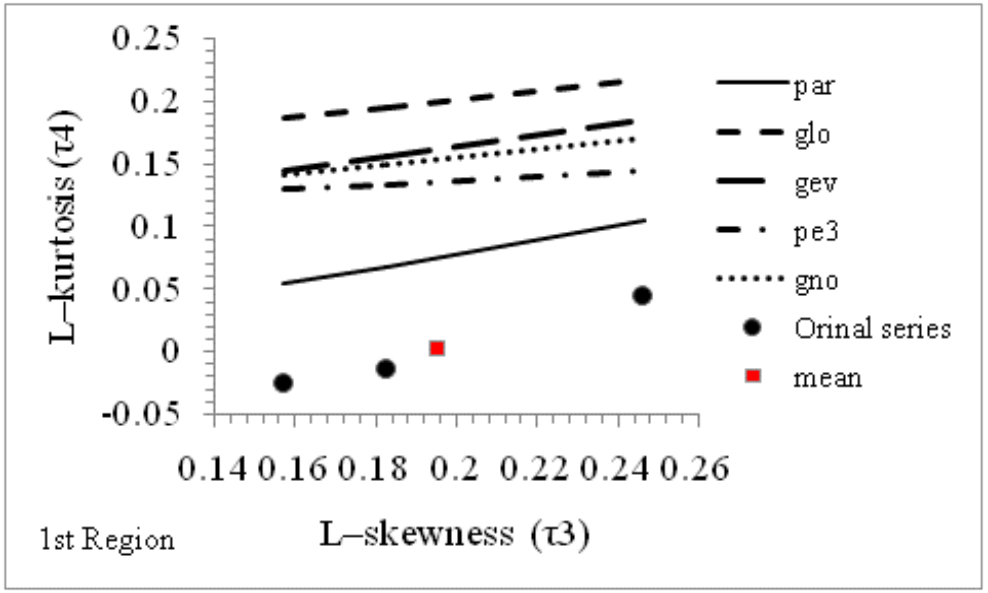

(a)

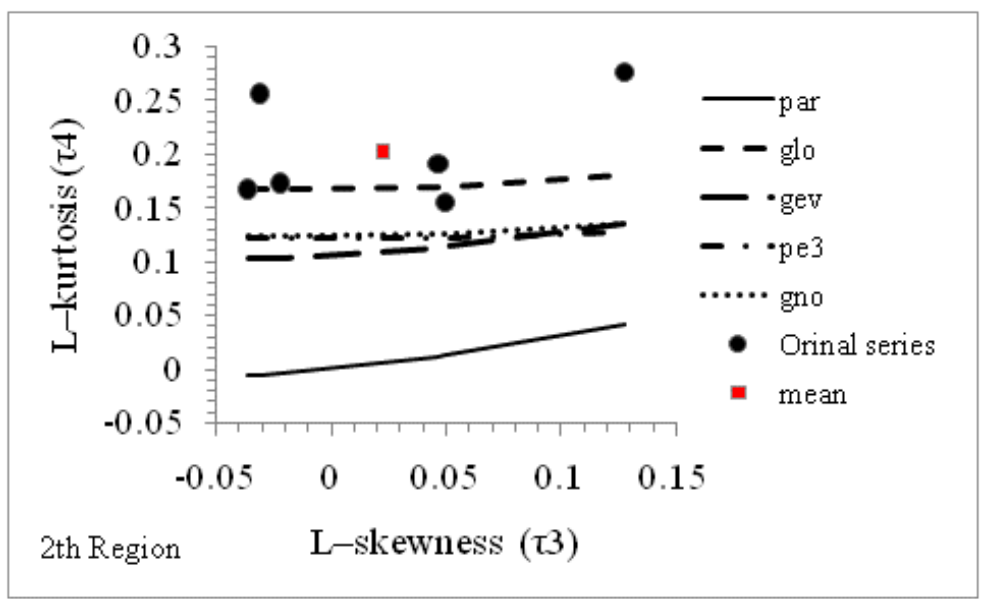

(b)

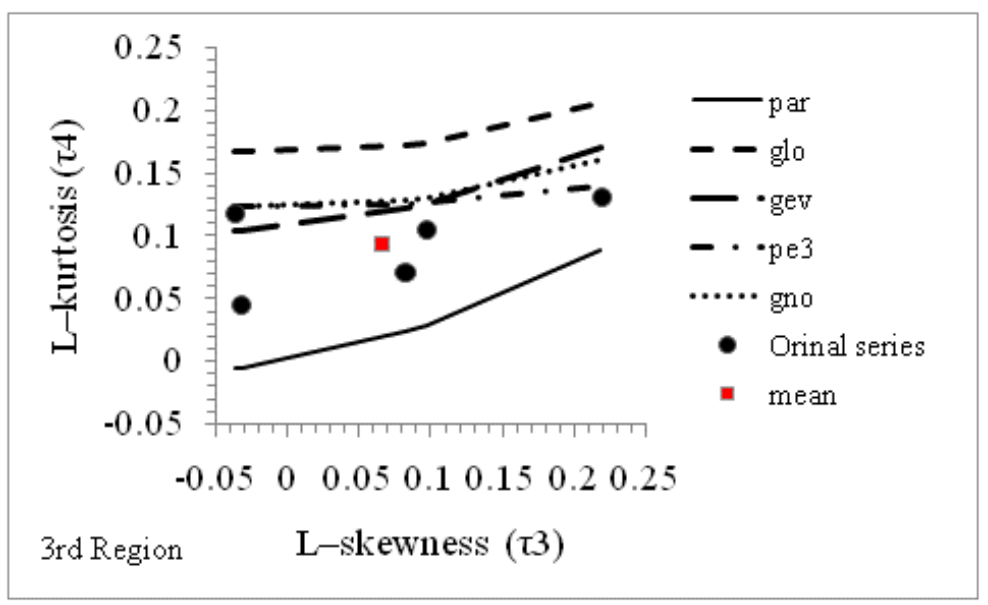

(c)

Figure 2. $\tau 4 \leftrightarrow \tau 3$ curves of the distributions for DO data and the $t 4 \leftrightarrow t 3$ theoretical values of the series (a) in the first (b) second and (c) third homogeneous regions 


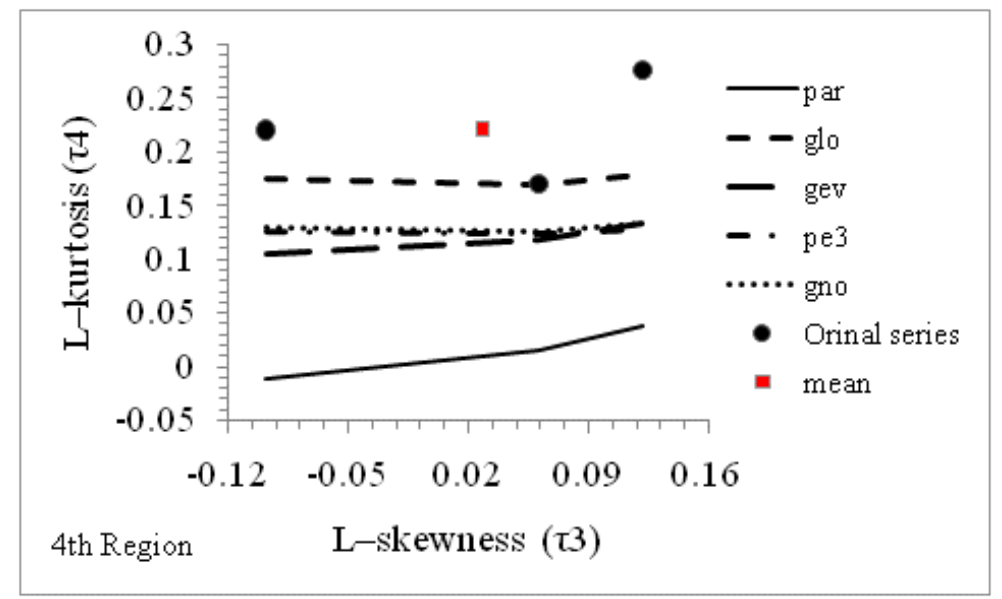

(a)

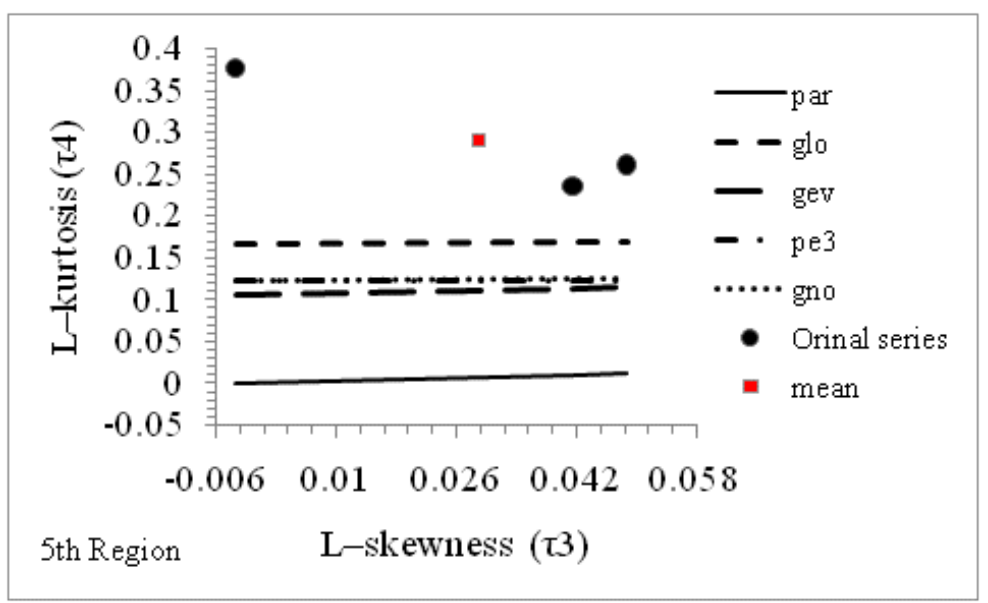

(b)

Figure 3. $\tau 4 \leftrightarrow \tau 3$ curves of distributions and $t 4 \leftrightarrow t 3$ theoretical values of series for many data (a) in the fourth and (b) fifth homogeneous region

After the discordance and homogeneity test, regional L-Skewness, L-Kurtosis and L-Variation coefficients were calculated separately for each region. During the calculation, the average values of the weight coefficients determined according to a point were used. These values were found by the ratio of the length of a series to the total length of a series. $\mathrm{Z}^{\mathrm{DIST}}$ values from synthetic series were obtained for all candidate distributions with equation 9 by regional L-coefficients and using 4-parameter - Kappa distribution. $Z^{\text {DIST }}$ test statistic values of GLO, GEV, PE III, GNO and GPA distributions are presented in Table 3. The result of the $\mathrm{Z}^{\text {DIST }}$ test statistic should be in the range $(-1.64,+1.64)$ for the probability distributions to reflect a region. For homogeneous regions, the distribution with the smallest $\mathrm{Z}^{\text {DIST }}$ value can be said to be the optimal distribution among the distribution and distributions that remain within the appropriate range of the $\mathrm{Z}^{\mathrm{DIST}}$ statistic. In other words, a homogeneous region can represent more than one distribution and the distribution with the smallest $\mathrm{Z}^{\text {DIST }}$ value is the optimal distribution. According to the results in table 3, obtained $\mathrm{Z}^{\mathrm{DIST}}$ statistic in the 3rd homogeneous region was 0.89 in the GEV distribution; 1.1 in the GNO distribution and 1.07 in the PE III distribution are the most suitable distributions for this region. Among these three distributions, the $\mathrm{Z}^{\mathrm{DIST}}$ value closest to zero value was found in the GEV distribution and it was found to be the most appropriate distribution. However, the Z ${ }^{\text {DIST }}$ values of GEV, GNO, GLO, PE III, GPA distributions for the four other regions outside the region were not within the appropriate range and these five distributions were not found to be appropriate. Therefore, the regionalization study of Sakarya Basin DO data was continued by using the Wakeby distribution proposed by Hosking.

In addition, besides the $\mathrm{Z}^{\mathrm{DIST}}$ statistic, the appropriate distribution can be determined visually by showing the $\mathrm{L}-$ Kurtosis values corresponding to the L-Skewness values on a graph. On the graph, we can say that if the average of the series is above or very close to the $\tau_{4} \leftrightarrow \tau_{3}$ curve, that distribution is a suitable distribution. L-Skewness/L-Kurtosis curves of distributions are given for the most data of homogeneous regions from 1 to 5 in Fig. 2-3. L-Skewness/L-Kurtosis values calculated from the data of the stations in the region and the average points of these point values are also shown in the graphs. According to Fig. 2, the average of L-Skewness/L-Kurtosis values in the third homogeneous region is seen from the graph that GEV distribution is the most appropriate distribution because the GEV distribution is closer to the L-Skewness/ L-Kurtosis curve. 
According to Fig. 2-3, the average of L- Skewness /L-Kurtosis values in the second and fourth homogeneous region is seen from the graph that GEV distribution is the most appropriate distribution. The distribution of GNO, GLO, GEV, GPA and PE III in other homogeneous sub-regions (regions 1 and 5) did not match the regions. Although close distribution is chosen in the visual method, the $\mathrm{Z}^{\mathrm{DIST}}$ statistic is more realistic. The average of L-Skewness/L-Kurtosis values were always desired to be right above the scatter line.

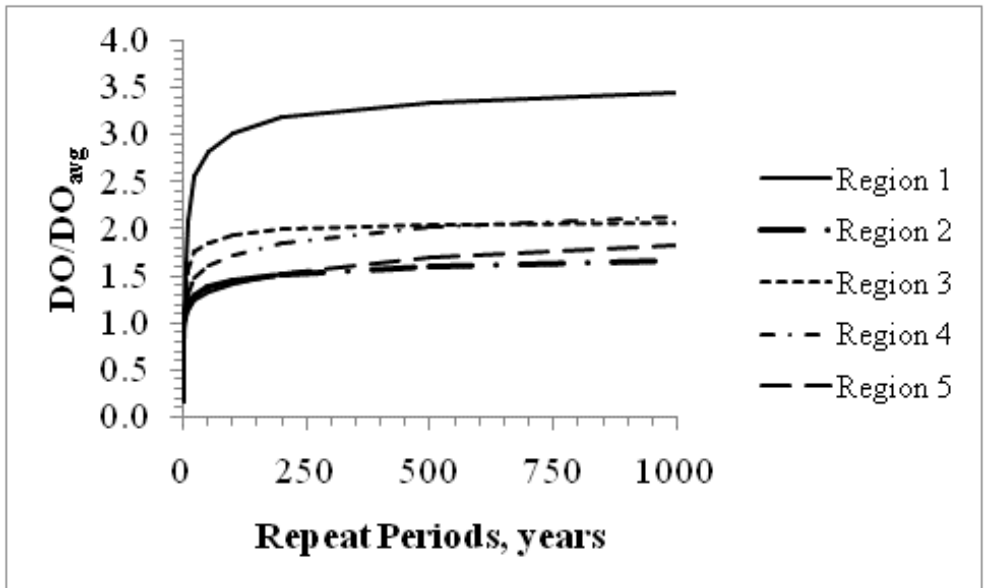

Figure 4. Repetition function graph for the repeat periods of 1.1, 1.25, 2, 5, 10, 25, 50, 100, 200, 500, 1000 years

Table 3. Z DisT compliance test results of the regions

\begin{tabular}{|c|c|c|c|c|c|}
\hline \multirow{2}{*}{$\begin{array}{l}\text { Basin } \\
\text { Areas }\end{array}$} & \multicolumn{5}{|c|}{$\begin{array}{c}\text { Results of } Z_{\text {Dist }} \text { Statistics for Potential } \\
\text { Distributions }\end{array}$} \\
\hline & GLO & GEV & GNO & PE İİI & GPA \\
\hline Region 1 & 4.47 & 3.65 & 3.47 & 3.10 & 1.78 \\
\hline Region 2 & -1.80 & -3.71 & -3.23 & -3.24 & -7.17 \\
\hline Region 3 & 2.48 & $0.89 *$ & $1.14^{*}$ & $1.07^{*}$ & -2.17 \\
\hline Region 4 & -2.13 & -3.20 & -2.96 & -2.98 & -5.18 \\
\hline Region 5 & -4.72 & -5.80 & -5.56 & -5.57 & -7.78 \\
\hline
\end{tabular}

Table 4. Wakeby distribution parameters at $90 \%$ significance level

\begin{tabular}{llllll}
\hline Basin Areas & $\begin{array}{l}\text { Location } \\
\text { Parameter }(\zeta)\end{array}$ & Alpha $(\boldsymbol{\alpha})$ & $\begin{array}{l}\text { Beta } \\
(\boldsymbol{\beta})\end{array}$ & Gamma $(\boldsymbol{\gamma})$ & $\begin{array}{l}\text { Delta } \\
(\boldsymbol{\delta})\end{array}$ \\
\hline Region 1 & 0.037 & 1.296 & 0.346 & 0.000 & 0.000 \\
Region 2 & 0.592 & 2.424 & 0.346 & 0.138 & -0.072 \\
Region 3 & 0.220 & 2.894 & 8.811 & 0.696 & -0.435 \\
Region 4 & 0.348 & 4.725 & 9.321 & 0.199 & -0.022 \\
Region 5 & 0.628 & 3.269 & 10.315 & 0.070 & 0.160 \\
\hline
\end{tabular}

Considering the results of $\mathrm{Z}_{\mathrm{DIST}}$ and visual conformity test, the study was continued by selecting the Wakeby distribution. Table 4 shows the statistical parameter values of the Wakeby distribution obtained with L-Coefficients calculated for all 5 homogeneous regions. According to Table 4, Wakeby distribution parameters were found for each region. Also, Wakeby distribution parameters are in different structures. The DO structure of each region is determined to be different with different parameters. According to the parameters calculated by Wakeby distribution, the repetition function of the common regional probability distribution, which is adapted to dimensionless DO data corresponding to the repetition periods of $1.1,1.25,2,5,10,25,50,100,200,500,1000$ years, is calculated and the repetition function is presented in Table 5. The D0 value of any station in the homogeneous regions will be calculated by using repeat function values in Table 5. In Fig. 4, the repetition function values are shown graphically. According to Fig. 4, the repetition function values were intersecting. The intersection of their values is quite normal. 
Table 5. Repeat function values of the common regional Wakeby distribution adapted to the dimensionless DO data corresponding to the Periodic Repeat Periods

\begin{tabular}{lllllll}
\hline $\begin{array}{l}\text { F } \\
\text { (Non- } \\
\begin{array}{l}\text { Exceeding } \\
\text { Chance) }\end{array}\end{array}$ & $\begin{array}{l}\text { T } \\
\text { (Recurrence } \\
\text { Period) }\end{array}$ & Region $\mathbf{1}$ & Region 2 & Region 3 & Region 4 & Region 5 \\
\hline 0.1 & 1.11111 & 0.171 & 0.782 & 0.490 & 0.686 & 0.846 \\
0.2 & 1.25 & 0.315 & 0.881 & 0.650 & 0.835 & 0.929 \\
0.5 & 2 & 0.836 & 0.999 & 0.964 & 0.991 & 0.996 \\
0.8 & 5 & 1.637 & 1.117 & 1.354 & 1.169 & 1.073 \\
0.9 & 10 & 2.095 & 1.200 & 1.561 & 1.301 & 1.139 \\
0.96 & 25 & 2.554 & 1.304 & 1.755 & 1.472 & 1.238 \\
0.98 & 50 & 2.816 & 1.378 & 1.857 & 1.600 & 1.324 \\
0.99 & 100 & 3.023 & 1.448 & 1.933 & 1.725 & 1.419 \\
0.995 & 200 & 3.185 & 1.515 & 1.990 & 1.849 & 1.526 \\
0.998 & 500 & 3.348 & 1.599 & 2.042 & 2.010 & 1.686 \\
0.999 & 1000 & 3.441 & 1.658 & 2.070 & 2.129 & 1.824 \\
\hline
\end{tabular}

In other parts of this study, regression equations were used to incorporate the relationship of all stations with other factors into regionalization. Regionalization by L-Moments method is performed using the average values of each station. As a result of the regionalization study, results are obtained according to the probability distributions determined and the mean values corresponding to repetition periods. Therefore, in order to estimate the average; DO data, the regression equation was developed using the average of the other factors. According to the results of the regression equation obtained, $\mathrm{DO}_{\text {avg }}$ values are multiplied by $\mathrm{DO} / \mathrm{DO}_{\text {avg }}$ repeat function (growth curve) in table 4 of the Wakeby probability distribution of the regions. Thus, the DO value of the actual scale corresponding to the return periods of each station was calculated.

In the estimation of $\mathrm{DO}_{\text {avg, }}$ regression equation covering all homogeneous regions was obtained and t-test, variance inflation factor (VIF) and f test were used. For regression equality, $\mathrm{Fe}, \mathrm{M}-\mathrm{Al}$, $\mathrm{Na}$ and $\mathrm{pV}$ variables of 20 stations belonging to Sakarya Basin were used. According to Table 6, the regression analysis summary for DO data averages is given. In a regression equation, the independent variables that can affect the dependent variable must supply the condition $t \geq t_{k r}$. As can be seen in table 6 , the arguments used in this study provided the $t \geq t_{k r}$ requirement and were used to estimate the DO value.

VIF statistics, which determine multiple interactions between independent variables, are used as input in the regression analysis. According to Table 6, the VIF values of all independent variables vary about 1.5. According to $\mathrm{VIF}$ analysis, it was found that $\mathrm{Fe}, \mathrm{Al}, \mathrm{Na}$ and organic material $(\mathrm{pV})$ variables were used as input in the regression equation.

The determination coefficient is a measure of how close regression analysis approaches the actual situation. In the regression analysis, the criterion for determining the coefficient of determination is $F \geq F_{k r}$. As can be seen in Table 6 , the $\mathrm{F}$ value was calculated as 31.04 and the critical $\mathrm{F}$ value in the $90 \%$ confidence interval was greater than 5.17 , which provided the condition of significance. As can be seen in Table 6 and Fig. 5, the coefficient of determination was found to be 0.8922 and it was found to be significant. 


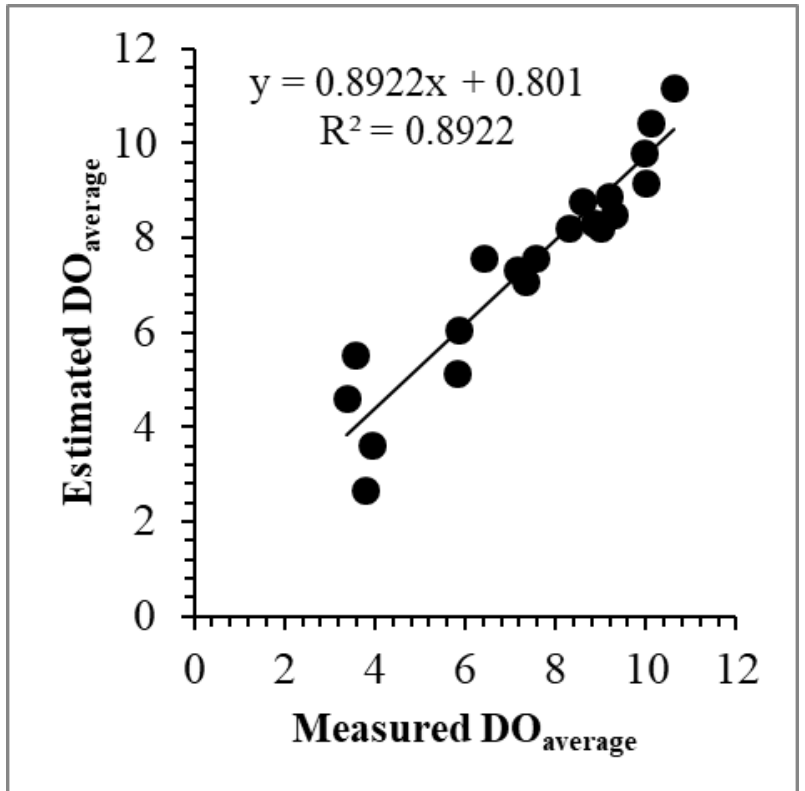

Figure 5. Estimated DO measured by regression analysis

Table 6. Summary values of regression analysis for DO estimation of mean DO data in 5 homogeneous regions in Sakarya Basin

\begin{tabular}{cccc}
\hline \multicolumn{3}{c}{$\%$ 90 Significance level tkr $=1.753$, Degree of freedom $=15$} \\
\hline $\begin{array}{c}\text { Descriptive } \\
\text { Variable }\end{array}$ & Coefficient Size & $\begin{array}{c}\text { The t Value of The } \\
\text { Coefficient }\end{array}$ & $\begin{array}{c}\text { Descriptive } \\
\text { Variable VIF Value }\end{array}$ \\
\hline Sabit & 11.228 & 20.33 & \\
Fe & -0.0008761 & -2.18 & 1.373 \\
M-Al & -0.007984 & -3.20 & 1.606 \\
$\mathrm{Na}$ & 0.018415 & 3.28 & 1.264 \\
$\mathrm{pV}$ & -0.27197 & -6.35 & 1.551 \\
$\mathrm{R}^{2}=0.8922$ & Fvalue $=31.04$ & $\mathrm{Fkr}=5.17$ & \\
\hline
\end{tabular}

In the continuation of the study, DO estimation maps were created by using GIS for the points where data could not be measured. For maps, IDW analysis was performed by using ArcGIS 10.5 package program. In this section real size DO data were used. The estimation maps of the real size DO data for 50-100-200-500-1000 year return periods obtained by the IDW method are given in Fig. 6-8. As shown in Fig. 6-8 excluding the 1000-year return period, all maps are similar. There are high DO values in the central region of the basin in maps of 50-100-200-500 year return periods (Fig. 6-9). Low DO values are observed in the small part of the western part of the basin in maps of 50-100-200-500 year return periods (Fig. 6-8). According to Fig. 8, The DO value in the maps of the 1000-year return period has gradually decreased and increased. The DO values in the maps of the 1000-year return period in the upstream section are quite low. The DO values in the maps of the 1000-year return period in the downstream section are higher than other maps. The number of stations used in the study is insufficient according to the size of the basin to create more sensitive maps. Particularly, the number of stations in the upstream section and should be increased. 


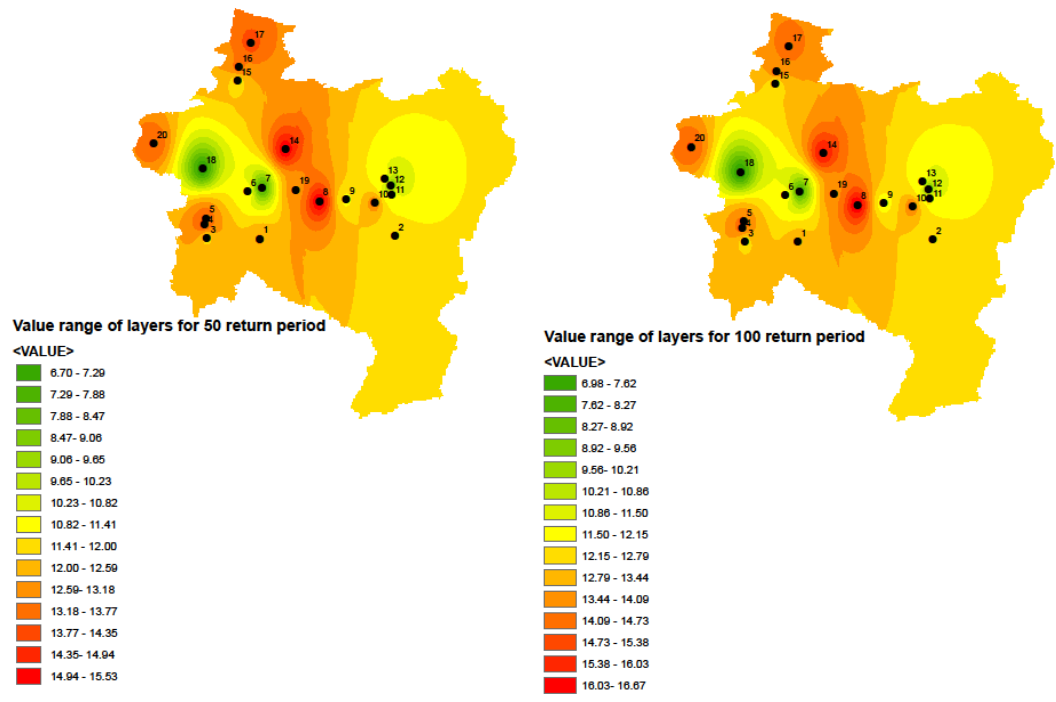

Figure 6. Derived IDW forecast map with a 50 and 100-year return period

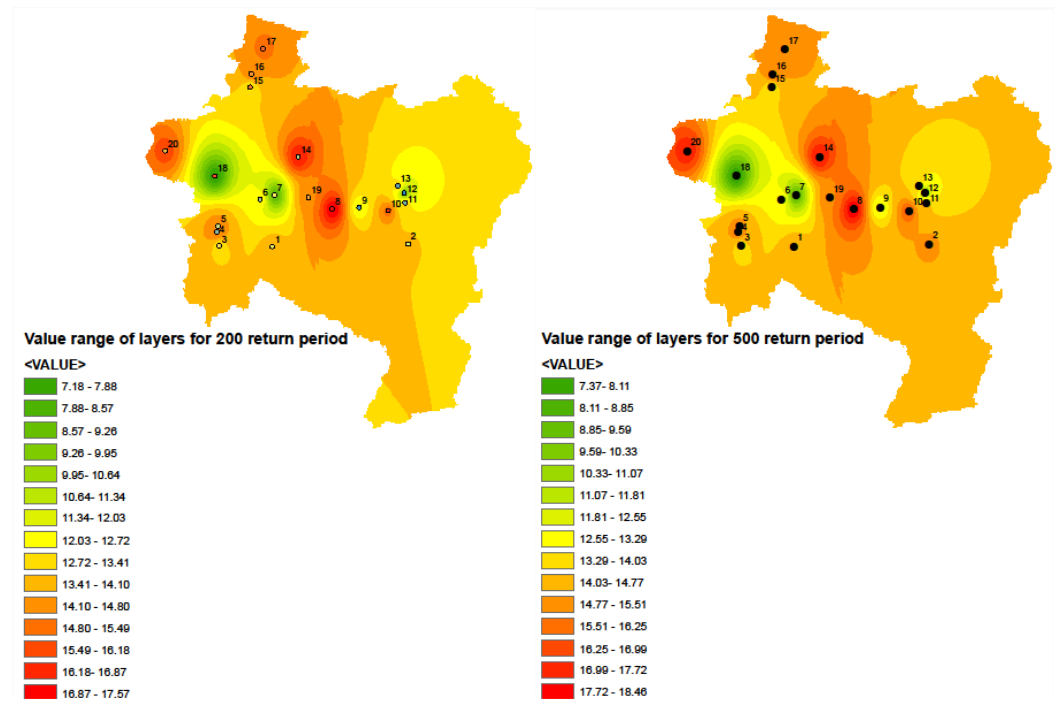

Figure 7. Derived IDW forecast map with a 200 and 500-year return period

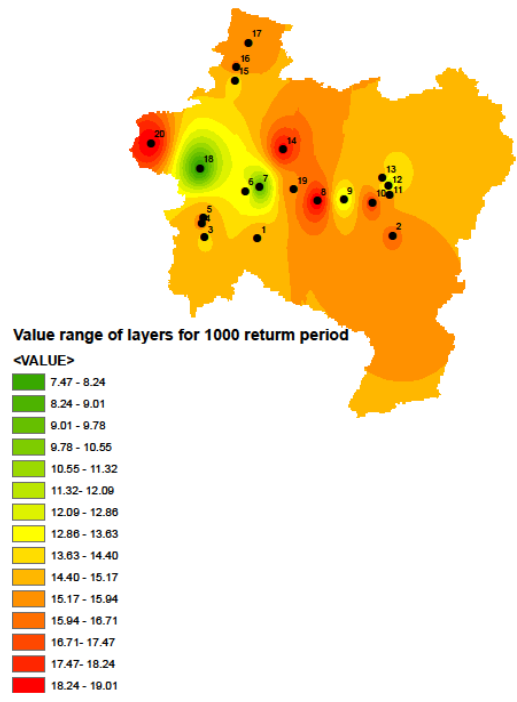

Figure 8. Derived IDW forecast map with a 1000-year return period 


\section{Conclusion}

The L-Moments Method was applied to 20 meteorological stations in the Sakarya Basin using recorded Dissolved Oxygen data observed for 20 years or more, including 2015. The results obtained from this study are as follows:

* All of the dissolved oxygen series were tested for Incompatibility, none of the 20 observation stations were found to be incompatible. (Discordance Test)

* The homogeneity test of the L-Moments method was applied to the dissolved oxygen series of 20 stations. According to this test, Sakarya Basin is not a single homogeneous region.

* According to homogeneity test, Sakarya Basin is divided into 5 sub-homogeneous regions.

* The theoretical parameter values of suitable candidate probability distributions of dissolved oxygen data were calculated and given by using L-Moments method. By using these parameter values, $\mathrm{Z}^{\mathrm{DIST}}$ statistic was calculated by considering the conformity test of L-Moments method for dissolved oxygen data. When the results of $\mathrm{Z}^{\mathrm{DIST}}$ statistics were evaluated, GEV distribution was found to be the most appropriate distribution for only the third homogeneous sub-region.

* According to the Z ZIST statistics in the other four regions, homogenous regions did not comply with GNO, GEV, GLO, GPA and PE III distributions.

* The regionalization study was continued with the Wakeby distribution.

* Geographically, in any location in the Sakarya Basin, the estimation of the mean of dissolved oxygen values $(\mathrm{Fe}),(\mathrm{Na}),(\mathrm{M}-\mathrm{Al})$ and $(\mathrm{pV})$ were used as independent variables and a coefficient of determination: $\mathrm{R}^{2}=0.892$ was developed.

* The DO maps of the Sakarya Basin were obtained by GIS for 50-100-200-500-1000 year return periods obtained by Wakeby probability distribution.

\section{Suggestions}

According to the L-moments method, the functions that can be performed in order to give the desired DO results for the predicted DO values for certain periods of return periods are as follows:

* L-Moments should be developed for further distributions in the literature.

* In order to provide better results for thematic DO estimation maps derived by IDW method, the stations of Sakarya Basin need to be increased.

* Water quality monitoring activities should be increased throughout the country, data should be monitored and necessary measures should be taken for resource management.

\section{Conflict of Interest}

No conflict of interest was declared by the authors.

\section{References}

Alley, W. M., and Burns, A. W., 1983. Mixed-station extension of monthly streamflow records. Journal of Hydraulic Engineering 109, 1272-1284. https://doi.org/10.1061/(ASCE)0733-9429(1983)109:10(1272).

Anlı, A.S., Apaydın H., Öztürk F., 2007. Regional Flood Frequency Estimation for the Göksu River Basin Through L-Moment, International River Basin Management Conference. State Hydraulic Works, pp 424-438, Gloria Golf Resort Hotel, Belek, Antalya, Turkey, 2007.

Ay, M., and Kisi, O., 2012. Modeling of dissolved oxygen concentration using different neural network techniques in Foundation Creek, El Paso County, Colorado. J. Environ. Eng., 138(6). https://dx.doi.org/10.1061/(ASCE)EE.1943-7870.0000511.

Chen, Y.D., Huang, G., Shao, Q., Xu, C.Y., 2006. Regional analysis of low flow using L-moments for Dongjiang basin, South China. Hydrological Sciences Journal 61(6), 1051-1064. https://doi.org/10.1623/hysj.51.6.1051.

Cheng, P., Li, X., Su, J., Hao, S., 2018. Recent water quality trends in a typical semi-1 arid river with a sharp streamflow decrease and sewage treatment plants construction. Environmental Research Letters, 13, 1-10. https://doi.org/10.1088/17489326/aa9df2.

Haktanir, T., Citakoglu, H., \& Acanal, N. 2013. Fifteen-stage operation of gated spillways for flood routing management through artificial reservoirs. Hydrological sciences journal, 58(5), 1013-1031.

Citakoglu, H. 2015. Comparison of artificial intelligence techniques via empirical equations for prediction of solar radiation. Computers and Electronics in Agriculture, 118, 28-37.

Citakoglu, H., Demir, V., Haktanır, T., 2017. Regional Frequency Analysis of Annual Flood Peaks of Natural Streams Discharging To The Black Sea By The L-Moments Method. Omer Halisdemir University Journal of Engineering Sciences 6(2), 571-580.

Dalrymple, T., 1960a. Flood Frequency Analysis,first ed. Geological Survey Water-Supply Paper 1543-A, Washington, D.C., USA. Dalrymple, T., 1960b.Flood Frequency Analysis, Water Supply Paper, 1543-A, U.S. Geological Survey, Washington, D.C.

Diamantini, E., Lutz, S. R., Mallucci, S., Majone, B., Merz, R., and Bellin, A., 2018. Driver detection of water qualitytrends in three large European river basins. Science of the Total Environment 612, 49-62. http://dx.doi.org/10.1016/j.scitotenv.2017.08.172. 
Doğan, H.M., Yılmaz, D.S., Kılıç, O.M., 2013. Orta Kelkit Havzası'nın Bazı Toprak Özelliklerinin Ters Mesafe Ağırlık Yöntemi (IDW) ile Haritalanması ve Yorumlanması. Gaziosmanpaşa Bilimsel Araştırma Dergisi. 6, 46-54.

Gonzales-Inca, C. A., Lepistö, A. and Huttula, T., 2016. Trend detection in water-quality and load time-series from agricultural catchments of Yläneenjoki and Pyhäjoki, SW Finland. Boreal Environment Research 21, 166-80.

Granger, S.J., Bol, R., Anthony, S., Owens, P.N., White, S.M., Haygarth, P.M., 2010. Chapter 3 - Towards a holistic classification of diffuse agricultural water pollution from intensively managed grasslands on heavy soils. In: Agronomy BT-A in, editor. Advances in Agronomy. vol. 105. Academic Press, pp. 83-115.

Greenwood, J.A., Landwehr, J.M., Matalas, N.C., Wallis, J.R., 1979. Probability Weighted Moments: Definition and Relation to Parameters of Several Distribution Exprensible in Inverse Form. Water Resources Research 15(5), 1049-1054. https://doi.org/10.1029/WR015i005p01049.

Haddeland, I., Heinke, J., Biemans, H., Eisner, S., Flörke, M., Hanasaki, N., Konzmann, M., Ludwig, F., Masaki, Y., Schewe, J., Stacke, T., Tessler, Z. D., Wada, Y., and Wisser, D., 2016. Global water resources affected by human interventions and climate change. P. Natl. Acad. Sci. USA, 111, 3251-3256. doi: 10.1073/pnas.1222475110.

Haktanir, T., Citakoglu, H., Seçkin, N., 2016. Regional frequency analyses of successive-duration annual maximum rainfalls by L-moments method. Hydrological Sciences Journal 61(4), 647-668. http://dx.doi.org/10.1080/02626667.2014.966722.

Halbe, J., Pahl-Wostl, C., Sendzimir, J., and Adamowski, J., 2013. Towards adaptive and integrated management paradigms to meet the challenges of water governance, Water Science and Technology 67(11), 2651-2660. DOI:10.2166/wst.2013.146.

Helsel, D. R., Hirsch, R. M., 2002. Statistical methods in water resources. techniques of water-resources investigations of the united states geological survey, Book 4, Hydrologic Analysis and Interpretation, Chapter A3, 524 pp.

Heperkan H., Kesgin U., 2003. Yazılım ve Programlama Uygulamalarıyla Mühendisler İçin Sayısal Yöntemler, 919-923. In: Numerical Methods For Engineers (Eds. Chapra, S.C., Canale, R.P.). Literatür Yayınevi Number: 82, İstanbul.

Hirsch, R.M., Douglas, L.M. and Stacey A.A., 2010. Weighted regressions on time, discharge, and season (WRTDS), with an application to Chesapeake bay river inputs. JAWRA 46, 857-880. https://doi.org/10.1111/j.1752-1688.2010.00482.x.

Hosking, J. R. M., Wallis, J. R., 1993. Some statistics useful in regional frequency analysis. Water Resour. Res. 29(2): 271-281. https://doi.org/10.1029/92WR01980.

Hosking, J. R. M., 1990. L-Moments: analysis and estimation of distributions using linear combinations of order statistics. Journal of the Royal Statistical Society, Series B: Statistical Methodology, 52, 105-124. https://doi.org/10.1111/j.25176161.1990.tb01775.x.

Hosking, J.R.M., Wallis, J.R., 1997. Regional Frequency Analysis An Approach Based on L-Moments, first ed. Cambridge University Press, London, UK.

Khalil, B., Awadallah, A.G., Adamowski J., Elsayed, A., 2016. A Novel Record-Extension Technique for Water Quality Variables Based on L-Moments. Water Air Soil Pollution 227(179), 1-20. http://dx.doi.org/10.1007/s11270-016-2852-9.

Kisi, O., Akbari, N., Sanatipour, M., Hashemi, A., Teimourzadeh, K., Shiri, J., 2013. Modeling of dissolved oxygen in river water using artificial intelligence techniques, Journal of Environmental Informatics 22, 92-101. doi:10.3808/jei.201300248.

Kumar, R., Chatterjee, C., 2005. Regional Flood Frequency Analysis Using L-Moments for North Brahmaputra Region of India. Journal of Hydrologic Engineering 10(1), 1-7. DOI: 10.1061/(ASCE)1084-0699(2005)10:1(1).

Kundzewicz, Z W. and Krysanova, V., 2010. Climate change and stream water quality in the multi-factor context, Clim. Change, 103(3-4), 353-362. DOI:10.1007/s10584-010-9822-9.

Mainali, J., Chang, H., 2018. Landscape and Anthropogenic Factors Affecting Spatial Patterns of Water Quality Trends in a Large River basin, South Korea. Journal of Hydrology 564, 26-40. https://doi.org/10.1016/j.jhydrol.2018.06.074.

Montgomery, D., Peck, E. A., Vining, G., 2001. Introduction to Linear Regression Analysis, 3rd edition. John Wiley, New York, $134 \mathrm{pp}$.

Seckin, N., Yurtal, R., Haktanır, T., Topaloğlu, F., 2010. Regional Flood Frequency Analysis of Ceyhan River Basin in Turkey Using L-Moments Method. Fresenius Environmental Bulletin 19(11a), 2616-2624.

Shanbehzadeh, S., Vahid Dastjerdi, M., Hassanzadeh, A., Kiyanizadeh, T., 2014. Heavy metals in water and sediment: a case study of Tembi River. J. Environ. Public Health, 28-34. doi: 10.1155/2014/858720.

URL: http://lib.stat.cmu.edu/general/lmoments (accessed 29 February 2020).

Yağbasan Özlem, Demir Vahdettin, Yazıcıgil Hasan (2020). Trend Analyses of Meteorological Variables and Lake Levels for Two Shallow Lakes in Central Turkey. Water, 12(414), 1-16., Doi: 10.3390/w12020414. 